\title{
ANALISIS KESALAHAN SISWA DALAM MENYELESAIKAN SOAL CERITA PADA MATERI PROGRAM LINEAR DITINJAU DARI GAYA KOGNITIF SISWA
}

\author{
Astri Andriyani 1), Novisita Ratu 2) \\ 1Pendidikan Matematika, Universitas Kristen Satya Wacana Salatiga, 202014090@student.uksw.edu \\ 2Pendidikan Matematika, Universitas Kristen Satya Wacana Salatiga, novisita.ratu@staff.uksw.edu
}

\section{INFO ARTIKEL}

Riwayat Artikel:

Diterima: 25-02-2018

Disetujui: 12-03-2018

\section{Kata Kunci:}

Gaya kognitif

Kesalahan konseptual

Kesalahan prosedural

Kesalahan teknik

\begin{abstract}
Abstrak: Penelitian ini adalah penelitian deskriptif kualitatif. Penelitian ini bertujuan untuk mengetahui kesalahan-kesalahan yang dilakukan siswa kelas XI SMA Negeri 1 Pabelan dengan gaya kognitif field independent, field independent semi, field dependent semi , dan field dependent dalam menyelesaikan soal cerita Program Linear. Gaya kognitif diukur dengan menggunakan tes GEFT. Subjek dalam penelitian ini adalah siswa dengan gaya kognitif $\mathrm{FI}, \mathrm{FI}_{\mathrm{S}}, \mathrm{FD}_{\mathrm{S}}$, dan $\mathrm{FD}$. Berdasarkan hasil tes dan wawancara diketahui bahwa subjek FI melakukan kesalahan teknik, subjek $\mathrm{FI}_{S}$ melakukan kesalahan teknik dan konseptual, subjek $\mathrm{FD}_{\mathrm{s}}$ melakukan kesalahan konseptual dan prosedural, dan subjek FD melakukan kesalahan kesalahan konseptual, prosedural, dan teknik
\end{abstract}

ABSTRAK

\begin{abstract}
This is a qualitative descriptive research. The purpose of the research is to know the faults of eleventh grade students of SMA N 1 Pabelan in solving /finishing story questions of linear program using cognitive styles field independent, field independent semi, field dependent semi , and field dependent cognitive styles is measured by GEFT. The subject of this research is the student with FI cognitive style, FIS, FDS, and FD. Based on the result of test and interview, the subject of FI did technique fault, FIS subject did technique and conceptual fauld, FDS subject did conceptual and procedural fauld, and FD subject did conceptual, procedural, and technique fauld
\end{abstract}

\section{A. LATAR BELAKANG}

Matematika merupakan ilmu yang sangat penting untuk dipelajari, oleh karena itu mata pelajaran ini selalu ada disetiap jenjang pendidikan. Permasalahanya adalah tidak sesuainya antara kemampuan siswa terhadap matematika yang disajikan oleh guru. Padahal yang diharapkan siswa menyukai matematika yang dapat diaplikasikan dalam kehidupan sehari-hari. Pengaplikasian matematika dalam kehidupan sehari- hari ini diwujudkan dalam soal cerita. Salah satu materi matematika yang berhubungan dengan soal cerita adalah materi program linear.

Fakta di lapangan menunjukan bahwa siswa masih saja kesulitan dalam menyelesaiakan soal cerita Program Linear, dengan sub materi nilai optimum. Hal ini dibuktikan oleh (Suci, 2015) dalam penelitianya dengan materi Program Linear (sub materi nilai optimum) terlihat banyak siswa yang melakukan kesalahan. Kesalahankesalahan yang dilakukan siswa ini meliputi kesalahan dalam membuat model matematika, kesalahan dalam menentukan titik pojok, dan tidak mengembalikan pada soal yang diminta. Berikut ini adalah contoh kesalahan yang dilakukan siswa dalam menyelesaikan soal cerita pada materi Program Linear (sub materi nilai optimum)

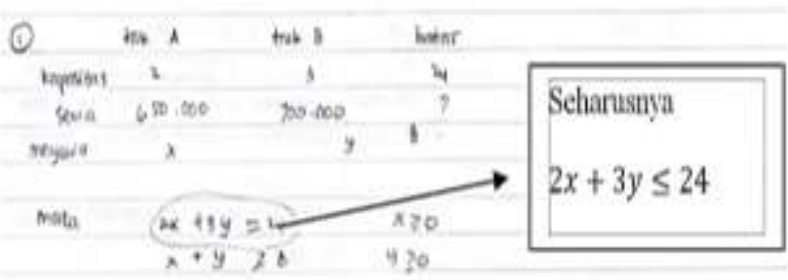

Gambar 1. Kesalahan dalam Membuat Model Matematika

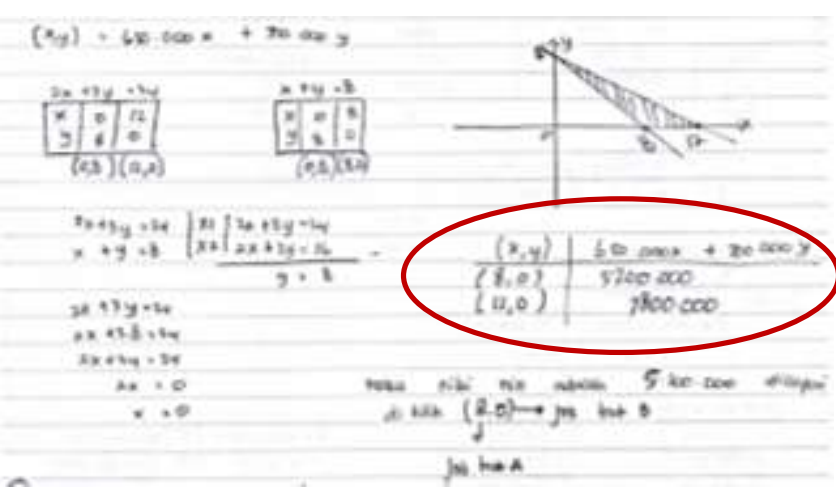

Gambar 2. Kesalahan dalam Menentukan Titik Pojok 


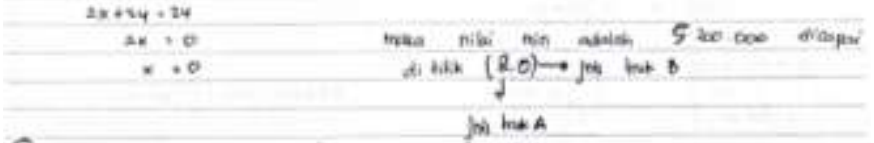

Gambar 3. Tidak Mengembalikan pada Soal yang Diminta

Kastolan dalam Sulistiyaningsih mengkategorikan kesalahan menjadi 3 yaitu, kesalahan konseptual, kesalahan prosedural, dan kesalahan teknik. Siswa melakukan kesalahan konseptual dalam menyelesaikan soal cerita Program Linear apabila siswa salah dalam menerapkan konsep pertidaksamaan linear, konsep menggambar grafik pertidaksamaan linear, konsep menentukan daerah penyelesaian, dan konsep-konsep lain dalam Program linear. Sedangkan siswa dikategorikan melakukan kesalahan prosedural apabila siswa tidak menuliskan pemisalannya dengan lengkap dan melakukan kesalahan dalam menyusun langkah-langkah menyelesaikan soal. Siswa dikategorikan melakukan kesalahan teknik apabila siswa melakukan kesalahan dalam perhitungan, dan melakukan kesalahan pada penulisan. Kesalahan-kesalahan yang dilakukan siswa tersebut perlu adanya analisis, dikarenakan banyaknya kesalahan siswa merupakan petunjuk tentang sejauh mana penguasaan siswa terhadap materi tersebut. Widiastuti (2014: 4) menyatakan bahwa sumber kesalahan yang sering dilakukan siswa harus segera mendapatkan pemecahan secara tuntas. Pemecahan ini ditempuh dengan cara menganalisis akar permasalahan yang menjadi faktor penyebab kesalahan yang dilakukan siswa. Selanjutnya diupayakan langkah-langkah pemecahannya secara tuntas dan meminimalkan kesalahan yang dilakukan.

Salah satu faktor internal yang perlu diperhatikan dalam menganalisis kesalahan siswa adalah gaya kognitif. Nasution (1988: 95) membedakan gaya kognitif menjadi dua yaitu field independent (FI) dan field dependent (FD). Menurut Slameto (1988: 163), gaya kognitif field independent adalah gaya yang dimiliki siswa yang cenderung menyatakan suatu gambaran lepas dari latar belakang gambaran tersebut dan mampu membedakan objek-objek dari konteks sebenarnya serta tidak dipengaruhi oleh lingkungan, sedangkan gaya kognitif field dependent berlaku sebaliknya. Adanya perbedaan gaya kognitif siswa ini akan mempengaruhi pola pikir dan perilaku siswa. Oleh karena itu, dalam menyelesaikan soal cerita pada materi program linear akan timbul beberapa pendapat yang berlainan dari masing-masing siswa yang menentukan benar atau salahnya jawaban siswa.

\section{B. METODE PENELITIAN}

Jenis penelitian ini adalah penelitian kualitatif dengan pendekatan diskriptif. Penelitian ini dilaksanakan pada bulan November 2017 di SMA Negeri 1 Pabelan. Lebih rincinya penelitian ini dilaksanakan pada hari Rabu-Kamis, 29-30 November 2017. Pada hari Rabu 29 November 2017 siswa melakukan tes GEFT sedangkan pada tanggal 30 November 2017 siswa mengerjakan soal cerita Program
Linear dengan sub materi nilai optimum, dilanjutkan wawancara untuk mengetahui alasan siswa yang melakukan kesalahan dalam menyelesaikan soal cerita.

Subjek dalam penelitian ini adalah seluruh siswa kelas XI IPS 1 yang memiliki gaya kognitif FI dan FD yang berjumlah 28 siswa. Selanjutnya akan dipilih 2 siswa FI dan 2 siswa FD untuk dilakukan wawancara.

Instrument utama dalam penelitian ini adalah peneliti sendiri serta didukung oleh instrumen bantu yang terdiri dari lembar tes dan pedoman wawancara yang sudah divalidasi oleh satu dosen dan satu guru matematika. Lembar tes sendiri terbagi menjadi dua. Pertama yaitu tes GEFT yang digunakan untuk mengetahui gaya kognitif siswa. Tes GEFT terdiri dari 18 soal, dimana subjek akan mendapatkan satu poin untuk satu soal benar dan mendapatkan nol poin untuk satu soal salah/ tidak dikerjakan. Kepner (1984: 1408) menyatakan "The classification of the students according to their cognitive styles namely Field Dependent (FD) and Field Independent (FI) is based on scores. Student within a range of 0-9 were identified as FD. Respondent scoring 10-18 were identified as FI". Pengkategorian gaya kognitif siswa menurut Kepner ini akan dikombinasikan dengan fuzzy logic dimana fuzzy logic ini digunakan untuk memperluas jangkauan fungsi karakteristik sedemikian hingga fungsi tersebut akan mencakup bilangan real pada interval $[0,1]$ Pengkategorian gaya kognitif siswa ini dapat dilihat dari gambar dibawah ini:

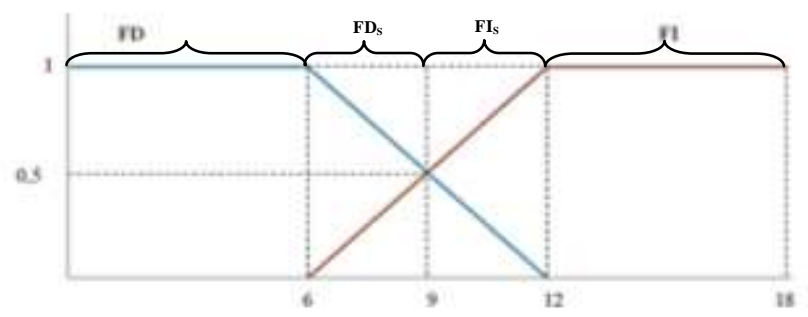

Gambar 4. Pengkategorian gaya kognitif siswa yang terdiri dari FD, FDs(FD semi), FIs(FI semi), dan FI

Berdasarkan gambar tersebut dapat dipahami bahwa siswa dengan skor $\geq 0$ dan $<6$ murni memiliki gaya kognitif FD, siswa dengan skor $\geq 6$ dan $<9$ memiliki gaya kognitif FD samar, siswa dengan skor $\geq 9$ dan $<12$ memiliki gaya kognitif FI samar, dan siswa dengan skor $\geq 12$ dan $\leq 18$ murni memiliki gaya kognitif FI.

Lembar tes yang kedua yaitu lembar tes yang berisi soal cerita Program Linear yang terdiri dari dua butir soal, satu soal nilai optimum maksimum, dan satu soal nilai optimum minimum. Penelitian ini tidak berfokus pada nilai akhir yang didapatkan siswa,akan tetapi lebih berfokus pada kesalahan-kesalahan yang dilakukan oleh siswa. Istrumen terakhir yang digunakan dalam penelitian ini adalah pedoman wawancara. Pedoman wawancara berisi pertanyaan-pertanyaan yang diajukan peneliti kepada subjek untuk menganalisis kesalahan yang dilakukan siswa dalam menyelesaikan soal cerita pada materi Program Linear. 
Teknik pengumpulan data yang digunakan dalam penelitian ini adalah teknik tes, wawancara, dan dokumentasi. Tes pada penelitian ini digunakan untuk mengetahui gaya kognitif yang dimiliki masing-masing siswa dan untuk mengetahui kesalahan kesalahan apa saja yang dilakukan siswa dengan gaya kognitif FI, FIs, FD, dan FDs dalam menyelesaikan soal cerita pada materi Program Linear.

Analisis yang digunakan dalam penelitian ini meliputi reduksi data, penyajian data, dan penarikan kesimulan. Data yang terkumpul kemudian dipilih hal pokok dan penting, kemudian disajikan dalam tabel agar mempermudah pembaca, dan diakhir akan ada kesimpulan dari peneliian ini.

\section{HASIL DAN PEMBAHASAN}

\section{Karakteristik FI, FIs, FD $_{s}$, dan FD}

Berdasarkan hasil tes GEFT yang melibatkan 23 siswa kelas XI IPS 1 SMA Negeri 1 Pabelan didapat, 10 siswa memiliki gaya kognitif FI, 6 siswa memiliki gaya kognitif $\mathrm{FI}_{\mathrm{S}}$, 3 siswa memiliki gaya kognitif $\mathrm{FD}_{\mathrm{S}}$, dan 4 siswa memiliki gaya kognitif FD. Selanjutnya peneliti mengambil masing-masing satu subjek FI, satu subjek FIs, satu subjek FDs, dan satu subjek FD untuk dilakukan wawancara, dimana wawancara ini bertujuan untuk menganalisis kesalahan siswa dalam mengerjakan soal cerita Program Linear dengan sub materi nilai optimum

Witkin dalam Kristanto (2016) mengklarifikasikan beberapa karakteristik individu yang memiliki gaya kognitif field independent, antara lain (1) memiliki kemampuan menganalisis untuk memisahkan objek dari lingkungan sekitar, sehingga persepsinya tidak terpengaruh bila lingkungan mengalami perubahan; (2) mempunyai kemampuan mengorganisasikan objek-objek yang belum terorganisir dan mereorganisir objek-objek yang sudah terorganisir; (3) cenderung kurang sensitif, dingin, menjaga jarak dengan orang lain, dan individualistis; (4) memilih profesi yang bisa dilakukan secara individu dengan materi yang lebih abstrak atau memerlukan teori dan analisis; (5) cenderung mendefinisikan tujuan sendiri, dan (6) cenderung bekerja dengan mementingkan motivasi intrinsik dan lebih dipengaruhi oleh penguatan intrinsik. Sedangkan individu dengan gaya kognitif $\mathrm{FI}_{S}$ tidak sepenuhnya memiliki karakteristik seperti yang dijelaskan di atas, namun ia tetap memiliki beberapa karakteristik seperti yang di jelaskan di atas.

Witkin dalam Kristanto (2016) mengklarifikasikan beberapa karakteristik individu yang memiliki gaya kognitif field dependent, antara lain (1) cenderung berpikir global, memandang objek sebagai satu kesatuan dengan lingkungannya, sehingga persepsinya mudah terpengaruh oleh perubahan lingkungan; (2) cenderung menerima struktur yang sudah ada karena kurang memiliki kemampuan merestrukturisasi; (3) memiliki orientasi sosial, sehingga tampak baik hati, ramah, bijaksana, baik budi dan penuh kasih sayang terhadap individu lain; (4) cenderung memilih profesi yang menekankan pada keterampilan sosial; (5) cenderung mengikuti tujuan yang sudah ada; dan (6) cenderung bekerja dengan mengutamakan motivasi eksternal dan lebih tertarik pada penguatan eksternal, berupa hadiah, pujian atau dorongan dari orang lain. Sedangkan individu dengan gaya kognitif $\mathrm{FI}_{\mathrm{S}}$ tidak sepenuhnya memiliki karakteristik seperti yang dijelaskan di atas, namun ia tetap memiliki beberapa karakteristik seperti yang di jelaskan di atas.

\section{Hasil Tes Program Linear}

Soal tes yang digunakan dalam penelitian ini adalah 2 soal cerita Program linear. Berdasarkan hasil tes dan wawancara yang dilakukan terhadap keenam subjek, maka dapat dianalisis kesalahan-kesalahan yang dilakukan subjek berdasarkan gaya kognitif yang mereka miliki. Berikut hasil analisis proses berpikir subjek pada setiap nomor soal.

Soal 1 : Di sebuah pameran, seorang sales diminta untuk menjual dua jenis krim pelembab yaitu krim A dan krim B. Sales tersebut harus dapat menjual krim A minimal 10 buah dan krim B minimal 20 buah. Jumlah kedua krim yang harus dijual tidak lebih dari 100 buah. Sales tersebut akan mendapatkan komisi Rp50.000,00 untuk setiap penjualan krim A dan Rp40.000,00 untuk setiap penjualan krim B. Jika banyaknya penjualan krim A tidak boleh melebihi 20 buah, maka berapakah keuntungan maksimum yang dapat diperoleh sales tersebu?

\section{a. Subjek FI}

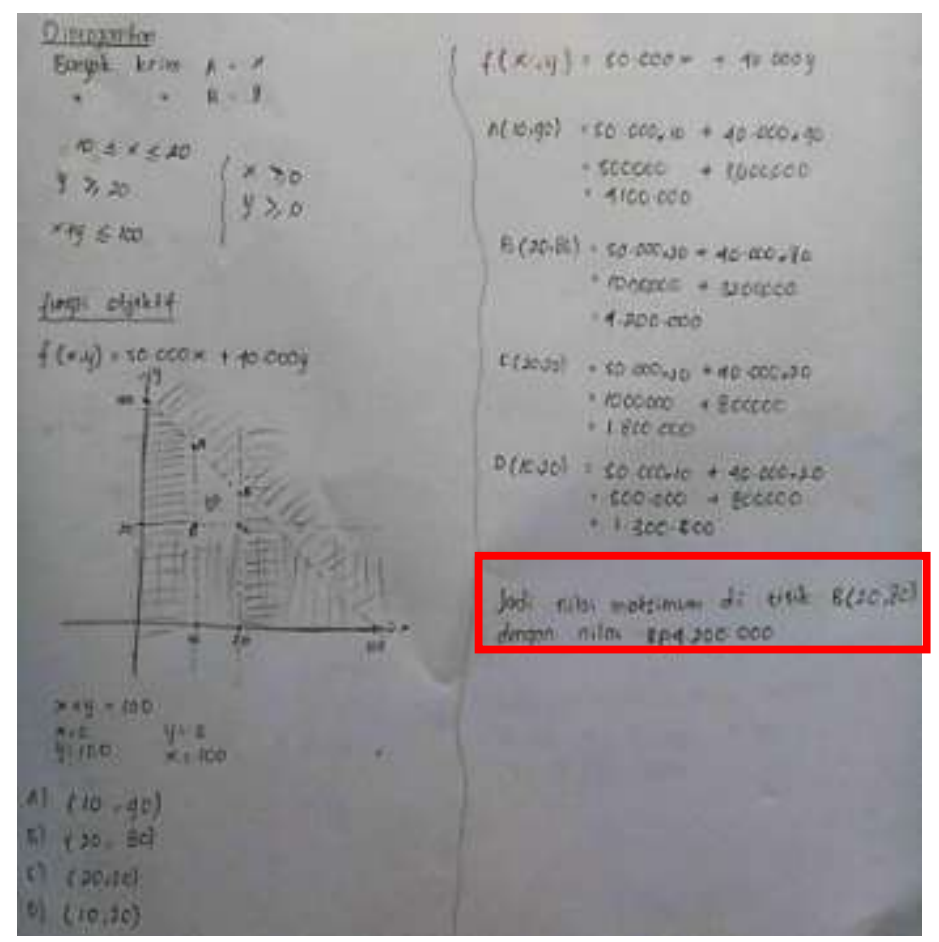

Gambar 5. Hasil tes subjek FI 
Subjek FI terlihat tidak melakukan kesalahan mulai dari membuat model matematika, menentukan fungsi objektif, menggambar grafik, menentukan daerah penyelesaian, menentukan titik pojok, melakukan perhitungan fungsi objektif, dan menentukan nilai akhir. Namun dalam penulisan nilai akhir subjek FI tidak mengembalikan jawabannya pada soal yang diminta, dimana dalam soal diminta untuk mencari berapakah keuntungan maksimum yang dapat diperoleh sales tersebut. Subjek FI hanya menuliskan nilai maksimumnya. Berikut adalah cuplikan wawancara dengan subjek FI

P : "yang ditanyakan dalam soal apa?"

S1 : "Nilai maksimumnya."

P : "Coba lihat soalnya, apa yang di cari?"

S1 : "Keuntungan maksimum yang diperoleh sales."

P : "Berarti Rp4.200.000 ini apa?"

S1 : "Keuntungan sales."

$\mathrm{P}$ : "Lalu kenapa kemaren jawabnya hanya nilai maksimumnya? Kok tidak ditulis keuntungan maksimum yang diperoleh sales?"

S1 : "Salah nulis itu."

Berdasarkan hasil tertulis, dan wawancara diketahui subjek FI melakukan kesalahan teknis, yaitu salah dalam menuliskan hasil akhir.

\section{b. Subjek FIS}

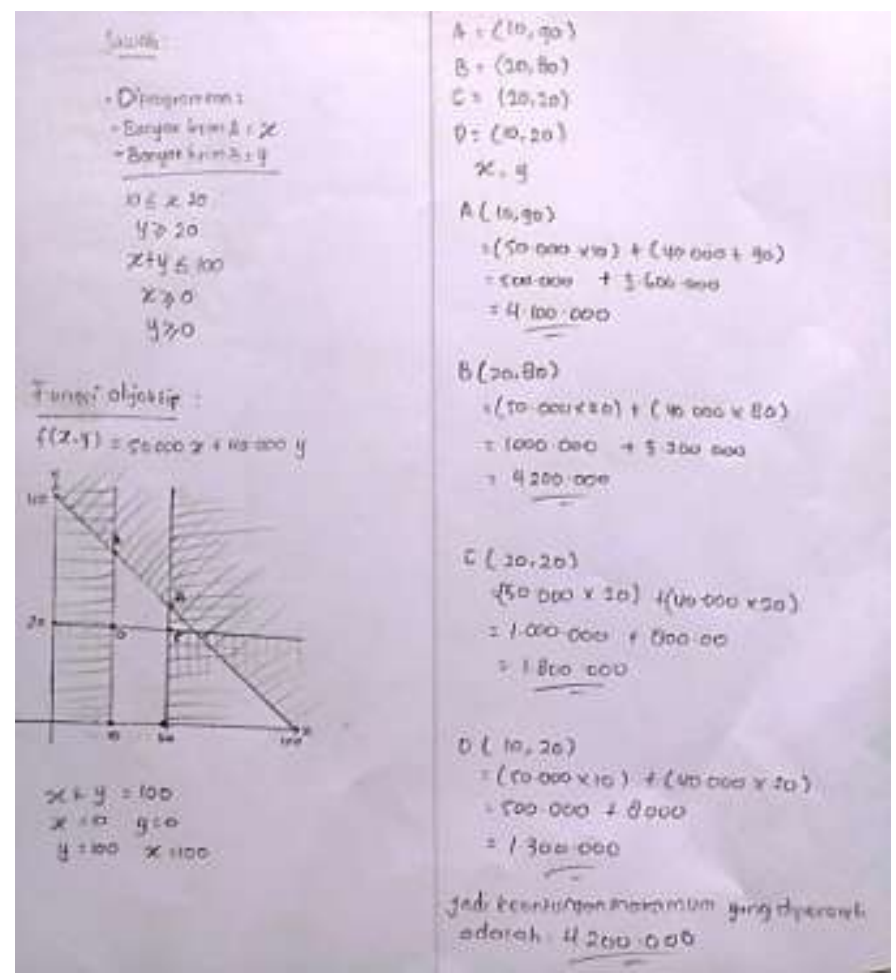

Gambar 6. Hasil tes subjek FIs

Kesalahan yang dilakukan subjek $\mathrm{FI}_{S}$ adalah salah dalam merepresentasikan masalah kedalam model matematika. Kesalahan ini terletak pada pertidaksamaan $10 \leq x 20$. Berikut adalah cuplikan wawancara dengan subjek FIs

$$
\text { P : “10 } \leq \text { x20 ini maksudnya apa?” }
$$

S2: “(diam sejenak) ohh, ini salah menghapus, tadinya mau menghapus yang ini (menunjuk angka 20) mau dipindah ke sini (menunjuk sebelah tanda $\leq$ yang sudah terlanjur dihapus) malah ini (menunjuk tanda $\leq$ yang sudah di hapus) yang kehapus."

P : "Lalu harusnya bagaimana?"

S2 : "Harusnya $10 \leq \mathrm{x} \leq 20$."

Berdasarkan hasil tertulis, dan wawancara diketahui subjek $\mathrm{FI}_{\mathrm{S}}$ melakukan kesalahan teknis, yaitu salah dalam menuliskan pertidaksaman.

Subjek $\mathrm{FI}_{\mathrm{S}}$ tidak melakukan kesalahan saat menentukan fungsi objektif, menggambar grafik, menentukan daerah penyelesaian, menentukan titik pojok, melakukan perhitungan fungsi objektif, dan menentukan nilai akhir.

\section{c. Subjek FD $s$}

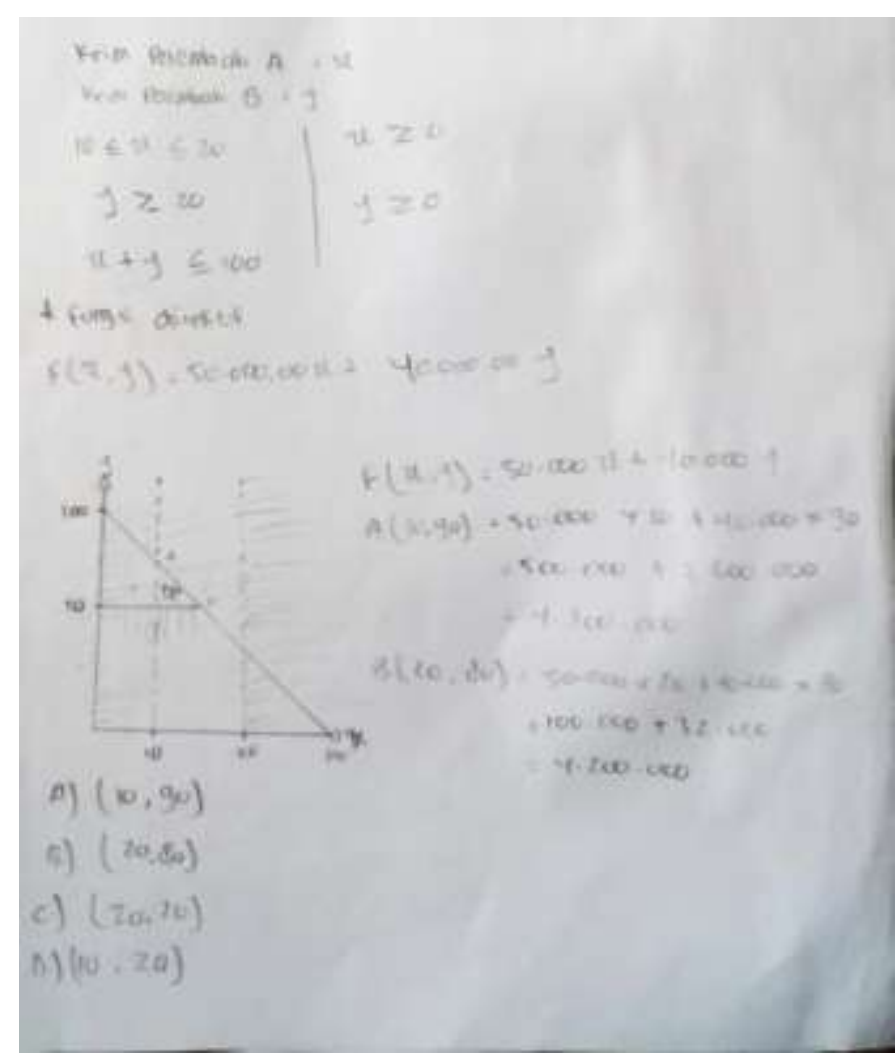

Gambar 7. Hasil tes subjek FDs

Subjek $\mathrm{FD}_{\mathrm{s}}$ melakukan kesalahan pada saat membuat pemisalan. Subjek hanya menuliskan krim pelembab $\mathrm{A}=x$ dan krim pelembab $\mathrm{B}=y$ dimana seharusnya $x$ adalah banyaknya krim A dan $y$ adalah banyaknya krim B. Kesalahan juga terlihat pada penggambaran grafik, dimana jarak tiap angka berbeda, hal ini mengakibatkan gambar terlihat tidak singkron. Kesalahan yang lain terletak pada perhitungan nilai akhir dan menentukan nilai akhir. Berikut adalah cuplikan wawancara dengan subjek $\mathrm{FD}_{\mathrm{s}}$

P : "Yang dimisalkan apa?"

S3 : "Krim A x , krim B y."

$\mathrm{P}$ : "Itu apanya?"

S3 : "Krimnya."

P : "Kalau misalnya 10 krim A jadinya bagaimana?" 
S3 : "10 x."

P : "Jadi x itu apa?"

S3 : "krimnya? " Apa?"

P : “Coba diingat, dulu diajarinya bagaimana?"

S3: "(menggeleng)"

P : "Yasudah, kalu ini (menunjuk gambar grafik), jarak 0 ke 20 sama jarak 0 ke 100 menurut kamu bagaimana."

S3 : "Tidak singkron ya?"

$\mathrm{P}$ : "Kenapa tidak singkron?"

S3 : "Asal gambar aja"

$\mathrm{P}$ : "Lalu ini langkah-langkahnya kenapa tidak dilanjutkan?"

S3 : "Bingung habis itu ngapain."

Berdasarkan hasil tertulis dan wawancara subjek $\mathrm{FD}_{\mathrm{s}}$ melakukan kesalahan konseptual pada pembuatan model matematika dan melakukan kesalahan prosedural pada perhitungan nilai akhir dan penentuan nilai akhir

\section{d. Subjek FD}

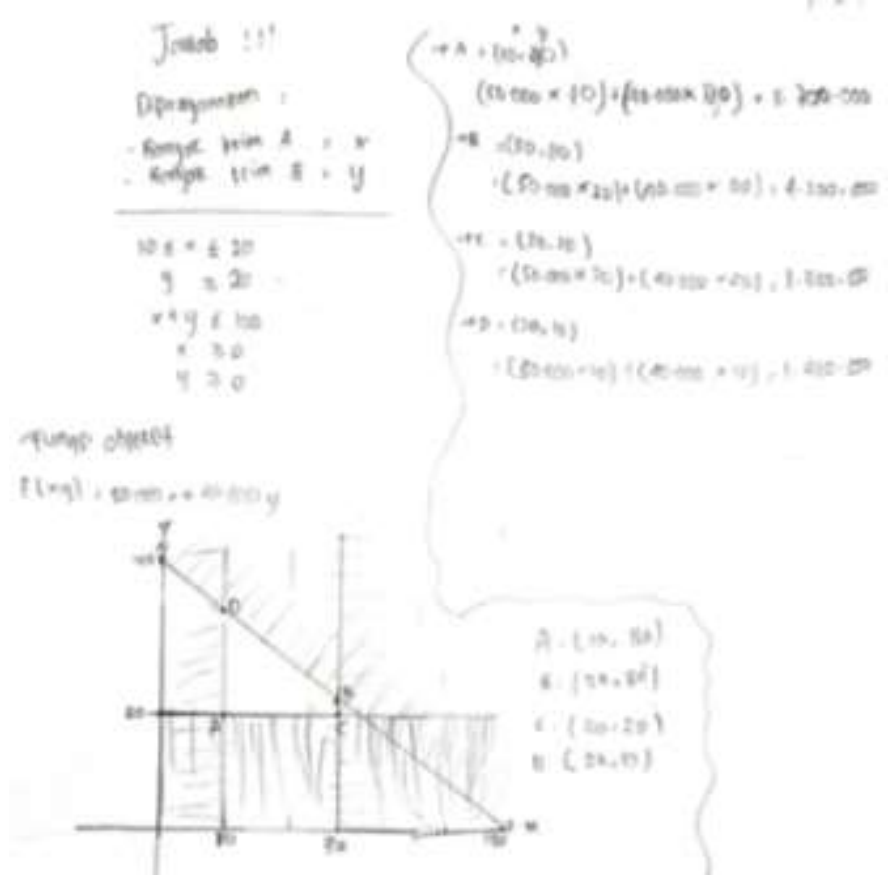

Gambar 8. Hasil tes subjek FD

Subjek FD melakukan kesalahan dalam penulisan titik pojok. Dimana berdasarkan gambar subjek FD titik A seharusnya adalah titik $(10,20)$, dan titik $\mathrm{D}(10,80)$. Kesalahan subjek FD juga terletak pada penulisan nilai akhir, dimana subjek FD tidak menuliskan nilai akhir dari soal cerita. Berikut adalah cuplikan wawancara dengan subjek FD

$\mathrm{P}$ : "Titik A nya yang mana?"

S4 : "Ini (menunjuk titik A pada gambar)."

$\mathrm{P}$ : "Kalau titik A nya yang ini seharusnya titiknya apa?"

S4 : "(20,10)."

P : "Lalu kenapa kamu menulisnya $(10,80) ? ”$

S4 : "Yang di gambar ini salah nulis titiknya. Titik A sama D nya terbalik."
P : "Jadi hasil akhirnya berapa?"

S4 : "Yang Rp4.200.000,00?"

$\mathrm{P}$ : "Kenapa tidak ditulis?"

S4 : "Kan sudah bisa dilihat, kelamaan."

Berdasarkan hasil tertulis dan wawancara kesalahan subjek FD dalam menuliskan titik pojok dikategorikan kedalam kesalahan teknis, sedangkan kesalahan subjek FD karna tidak menuliskan nilai akhir dikategorikan kesalahan prosedural.

Soal 2 : Karang taruna Damai akan mengadakan karya wisata ke Dieng Plateu dengan menggunakan bus. Panitia karya wisata, mensurvei dua jenis bus, yaitu bus A dan bus B. Hasil survei diperoleh bahwa, bus jenis $A$ memiliki kapasitas 40 orang dengan harga Rp2.500.000,00, sedangkan bus jenis B memiliki kapasitas 60 orang dengan harga Rp4.000.000,00. Jika banyak remaja yang mengikuti karya wisata adalah 360 orang, maka pengurus karya wisata menyewa bus sekurang kurangnya 7 unit. Berapa biaya minimum yang harus dikeluarkan oleh panitia?

\section{a. Subjek FI}

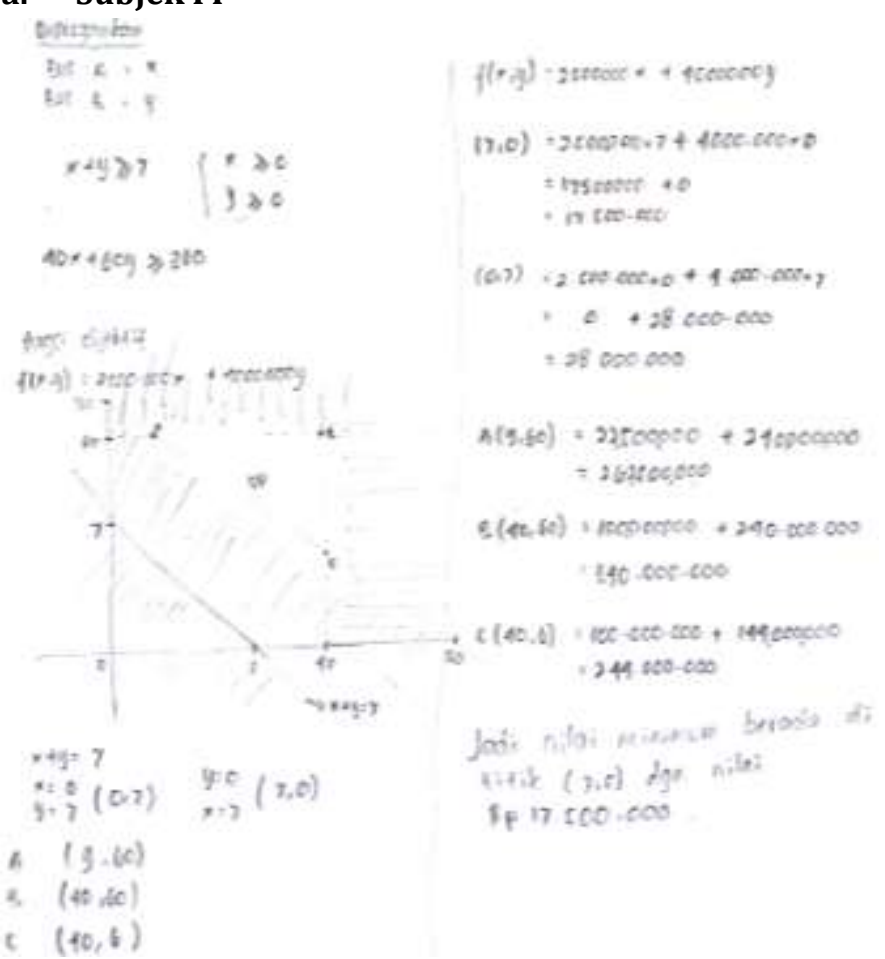

Gambar 9. Hasil tes subjek FI

Subjek FI melakukan kesalahan saat menggambar grafik $40 x+60 y=360$ hal ini mengakibatkan kesalahan berlanjut pada penentuan titik pojok, dan penulisan nilai akhir. Namun karena subjek FI tidak menyadarikesalahanya subjek FI tetap melanjutkan pekerjaany.Berikut adalah cuplikan wawancara dengan subjek FI

$\mathrm{P}$ : "Coba tunjukan grafik $40 \mathrm{x}+60 \mathrm{y}=360$ yang ditanyakan dalam soal apa?"

S1 : "(melihat gambar)."

P : “40x $+60 y=360$ kalu disederhanakan jadi apa?" 
S1 : “ $2 x+3 y=18$. oh iya ini gambarnya salah, ini harusnya yang dimisalkan $\mathrm{x}=0$ sama $\mathrm{y}=0 \mathrm{itu}$ kan. Yah berarti ini salah semua?"

P : "Prosedurnya sudah benar hanya saja kesalahan ini mengakibatkan kesalahan pada proses selanjutnya. Kenapa gambarnya bisa salah?"

S1: "La ini angkanya besar, lupa kalok bisa disederhanakan."

Berdasarkan hasil tertulis dan wawancara subjek FI pada dasarnya melakukan kesalahan konseptual, namun setela adanya wawancara ternyata subjek FI mampu menjelaskan proses yang benar, hanya saja ia lupa untuk menyederhanakanya. Oleh karena itu kesalahan subjek FI ini dikategorikan kedalam kesalahan teknis

\section{b. Subjek FIs}
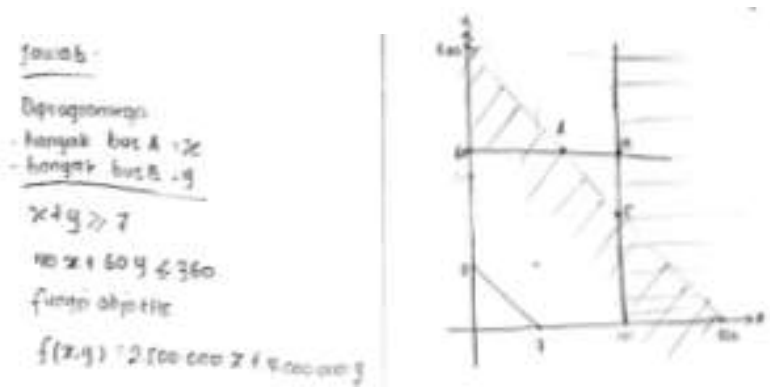

Gambar 10. Hasil tes subjek FIs

Subjek FIs Melakukan kesalahan padasaat menggambar grafik $40 x+60 y=360$ hal ini mengakibatkan subjek FIs tidak melanjutkan pekerjaanya. Berikut cuplikan wawancara dengan subjek FIs

P : "Kenapa jawabanya tidak di lanjutkan?"

S2 : "Gambar grafik 40x $+60 y=360$ ini gak bias."

P : "Apa belum pernah diajarkan sebelumnya."

S2 : "Lupa."

Berdasarkan hasil tertulis dan wawancara kesalahan subjek $\mathrm{FI}_{\mathrm{s}}$ dikategorikan kesalahan konseptual. Dimana konsep mengambar grafik $a x+b y=c$ dimana a dan $b \neq 1$ tidak ia kuasai.

\section{c. Subjek FDs}

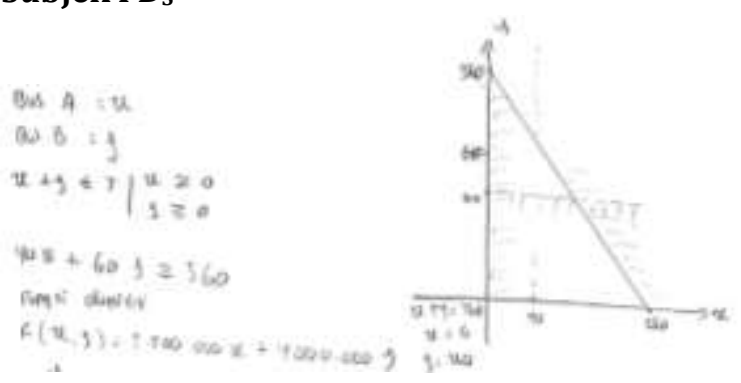

Gambar 11. Hasil tes subjek FDs

Subjek FDs Melakukan kesalahan dalam merepresentasikan masalah kedalam model matematika. Seharusnya tanda yang digunakan adalah $(\geq)$. Kesalahan juga terjadi pada saat menggambar grafik $40 x+60 y=360$ hal ini mengakibatkan subjek FIs tidak melanjutkan pekerjaanya. Pekerjaan subjek FI terhenti pada langkah menggambar grafik. Berikut cuplikan wawancara dengan subjek FIs

P : "Pengurus karya wisata menyewa bus sekurangkurangnya 7 unit. Sekurang-kurangnya berarti boleh kurang tidak?"

S3 : "Tidak."

P : "Maka tandanya harusnya bagaimana?"

S3 : “( $\geq)$."

$\mathrm{P}$ : "lalu kenapa jawabanmu ( $\leq$ )."

S3 : "Tadi belum paham maksud soal."

P : “Apa kata-katanya membingungkan?"

S3 : "Tidak, cuman tadi membacanya tidak diulangulang jadi sekali baca."

P : "Lalu kenapa jawabanya ini tidak dilanjutkan?"

S3 : "Gambar grafik 40x $+60 y=360$ gak bias."

$\mathrm{P}$ : "Apa belum pernah diajarkan?"

S3 : "Mungkin sudah, tapi lupa."

Berdasarkan hasil tertulis dan wawancara kesalahan subjek $\mathrm{FI}_{\mathrm{s}}$ dalam membuat model matematika dikategorikan kesalahan konseptual, dimana kesalahan ini diakibatkan karena subjek kurang memahami soal. Kesalahan konseptual juga dilakukan subjek dimana ia tidak bisa menggambar grafik $40 x+60 y=360$.

\section{d. Subjek FD}
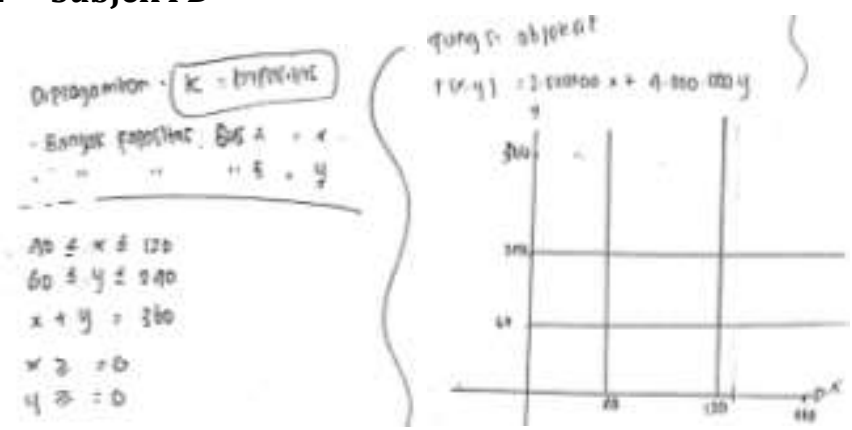

Gambar 12. Hasil tes subjek FD

Subjek FD melakukan kesalahan dalam membuat model matematika, dan salah dalam menulis tanda pertidaksaman. Hal ini berakibat pada kesalahan dalam langkah selanjutnya. Berikut adalah cuplikan wawancara dengan subjek FD

P : “40 $\leq \mathrm{x} \leq 120$ maksudnya apa?”

S4 : "Kan yang ikut karya wisata 360 , jadi yang ikut bis A 120 yang ikut bus B 240, jumlahnya 360."

P : "Dari mana angka 120 dan 240 ?"

S4 : "Dicoba-coba saja."

Berdasarkan hasil tertulis dan wawancara kesalahan subjek FD dalam membuat model matematika dikategorikan kesalahan konseptual. Kesalahan subjek FD dalam membuat model matematika ini akan berakibat pada kesalahan pada langka-langkah selanjutnya. 


\section{SIMPULAN DAN SARAN}

Berdasarkan hasil penelitian dan pembahasan, berikut ini adalah kesimpulan dari analisis kesalahan siswa dalam menyelesaikan soal cerita Program Linear, yang tercantum dalam tabel.

TABEL 1

HASIL ANALISIS KESALAHAN SUBJEK FI, FIs, FDs, dan FD

\begin{tabular}{|c|c|c|}
\hline $\begin{array}{c}\text { Soal } \\
1\end{array}$ & Jenis Kesalahan & $\begin{array}{c}\text { Kategori } \\
\text { Kesalahan }\end{array}$ \\
\hline FI & Salah menulis nilai akhir & Teknik \\
\hline FIs & Salah menulis model matematika & Teknik \\
\hline FDs & $\begin{array}{l}\text { Salah membuat pemisalan dalam model } \\
\text { matematika } \\
\text { Salah dalam membuat grafik } \\
\text { Perhitungan nilai akhir yang tidak } \\
\text { lengkap } \\
\text { Tidak menuliskan nilai akhir }\end{array}$ & $\begin{array}{l}\text { Konseptual } \\
\text { dan } \\
\text { Prosedural }\end{array}$ \\
\hline FD & $\begin{array}{l}\text { Salah dalam menuliskan titik pojok } \\
\text { Tidak menuliskan nilai akhir }\end{array}$ & $\begin{array}{l}\text { Teknis dan } \\
\text { Prosedural }\end{array}$ \\
\hline $\begin{array}{l}\text { Soal } \\
2\end{array}$ & Jenis Kesalahan & $\begin{array}{l}\text { Kategori } \\
\text { Kesalahan }\end{array}$ \\
\hline FI & $\begin{array}{l}\text { Salah perhitungan dalam mengambar } \\
\text { grafik }\end{array}$ & Teknik \\
\hline FIs & Salah dalam mengambar grafik & Konseptual \\
\hline FDs & $\begin{array}{l}\text { Salah dalam membuat model } \\
\text { matematika } \\
\text { Salah dalam mengambar grafik }\end{array}$ & Konseptual \\
\hline FD & $\begin{array}{l}\text { Salah dalam membuat semua model } \\
\text { matematika } \\
\text { Salah dalam menggambar grafik } \\
\text { Tidak menuliskan titik pojok } \\
\text { Tidak melanjutkan pekerjaanya }\end{array}$ & Konseptual \\
\hline
\end{tabular}

Adapun saran bagi peneliti lain, hendaknya penelitian ini dapat dijadikan acuan dalam penelitian selanjutnya, agara dapat ikut berkontribusi dalam rangka peningkatan mutu pembelajaran indonesia. Sedangkan bagi guru hendaknya kesalahan pada siswa ini dapat dijadikan sebagai acuan agar kesalahan ini tidak terulang lagi, atau paling tidak mengurangi resiko terjadinya kesalahan, karena ditakutkan kesalahan ini akan dibawa sampai pada materi-materi selanjutnya, mengingat mata pelajaran matematika adalah matapelajaran yang saling berkaitan.

\section{UCAPAN TERIMA KASIH}

Penulis mengucapkan terima kasih kepada dosen pembimbing, guru matematika serta siswa kelas XI IPS 1 SMA Negeri 1 Pabelan yang telah membantu dalam penelitian ini.

\section{DAFTAR RUJUKAN}

[1] Kepner, MD, \& Neimark, ED. 1984. "Test-retest Reliability and Differensial Pattern of Score Change on the Group Embedded Figures Test". Journal of Personality and Social Psychology, 46 (6), 1405-1413.

[2] Kristanto, BR. 2016. "Analisis Proses Berpikir dalam Menyelesaikan Soal Geometri Ditinjau dari Gaya Kognitif Fild Independent Dan Fild Dependent Pada Siswa Kelas VIII SMP 4 Boyolali". Skripsi. Universitas Kristen Satya Wacana.

[3] Nasution, S.1988. Berbagai Pendekatan dalam Proses Belajar dan Mengajar. Jakarta: Bina Aksara
[4] Suci, RD. 2015. "Analisis Kesalahan Siswa dalam Menyelesaikan Soal Cerita Program Linear Pada Siswa Kelas XI MIA Semester 1 SMA Negeri Jakenan Pati Tahun Pelajaran 2014/2015". Skripsi. Universitas Sebelas Maret Surakarta. diperoleh dari (file:///C:/Users/AstriAndriyani/Downloads/badi.pdf) (diakses pada 4 Febuari 2017)

[5] Sulistiyaningsih, A. 2017. Analisis Kesalahan Sisa menurut Kastolan dalam Pemecahan Masalah Matematika.Seminar matematika dan pendidikan matematika UNY

[6] Widdhiastutu . 2014. Analisis Kesalahan Siswa dalam Menyelesaikan Soal Uraian Matematika Berbentuk Cerita pada Pokok Bahasan Sistem Persamaan Linier Dua Variabel (SPLDV) Kelas VIII Semester Gasal SMP Negeri 2 Ngemplak Boyolali Tahun Ajaran 2013/2014. Skripsi. Universitas Muhamadiyah Surakarta. diperoleh dari (http://eprints.ums.ac.id/29694/4/04.BAB I.pdf ) (diakses pada 4 Febuari 2017) 